\title{
关于高层建筑施工技术关键要点的思考
}

\author{
李婷婷 \\ 广西建工集团第一建筑工程有限责任公司 \\ DOI:10.32629/btr.v2i7.2335
}

[摘 要] 如今, 高层建筑现已成为城市建设的主要标志, 其不仅解决了城市人口居住问题, 也推进了城市化建设的快速发展。而 施工技术是高层建筑的重要环节,合理把控施工技术要点, 能够有效提高高层建筑的建设质量。为此, 本文就对高层建筑施工技 术的关键要点进行了探讨和分析, 以供参考。

[关键词] 高层建筑; 施工技术; 关键要点

在现今城市发展中, 高层建筑施工已经成为人们关注的 重点内容, 而社会也对施工技术的要求愈发严格。所以加强 对高层建筑施工技术要点的分析, 对于提供高层建筑施工质 量有着重要的现实意义。

\section{1 高层建筑施工特征}

21 世纪后, 建筑行业的发展步伐逐渐加快, 施工技术水 平也在逐渐提高, 原有单一形式的建筑结构也逐渐被复杂的 高层建筑结构所取代, 并成为城市建设的主要风向标。同传 统的建筑结构相比, 高层建筑的特征主要有:

1.1 自重大、承载能力要求高

地基是保证建筑稳固性的重要组成部分, 地基承载能力 越强, 相应的建筑稳固性和安全性也就越高。对于高层建筑 来说, 随着高度的增加, 地基承受的重力也在加大, 对承载能 力的要求也会越来越高。

\section{2 施工周期较长}

普通建筑和多层建筑的施工时间一般在一年左右, 高层 建筑的施工时间则在三年左右, 如果高度增加, 施工时间则 要增加到 5 年也是有可能的。而为了缩短施工周期, 企业一般 会改变施工结构或者提高装饰质量等方式进行。另外, 在浇 筑过程中, 改进模板质量也是缩短工期的有效措施。

\section{3施工条件较为复杂}

高层建筑大多建在城市的中心地带, 人流、车流、建筑 物都相对较多, 这使得施工作业的开展会受到多方面因素的 影响。另外, 在高层建筑施工中, 还要做好保护工作, 避免因 结构开裂而引发的危险事故。

\section{2 高层建筑施工技术要点}

2. 1 基坑围护技术要点

基坑围护是保证高层建筑结构施工安全的一种手段, 其 具有挡土、支护、防水和降水等功能, 通过该技术的应用能 够在维护高层建筑施工安全的基础上, 缩短施工工期, 减少 成本支出。基坑围护的方式主要有顺作法和逆作法两种。其 中顺作法包含放坡、重力式围护、板式围护这三种形式; 逆 作法包括全逆作法、半逆作法和局部逆作法这三种。由于形 式的不同, 各种基坑围护方式的使用范围以及成本投入也存 在一定的差异。例如, 重力坝、钢板桩以及复合土钉墙这三
种围护方式, 虽然都应用于深度在 5 米左右的基坑, 但是其价 格却大有不同, 所以在实际施工作业中, 应结合具体情况, 科 学选择基坑围护方式。

\section{2 悬挑式脚手架施工要点}

悬挑式脚手架施工技术的应用是为了确保高层建筑结 构主体及装修作业的安全, 具有很好的防护效果。通常情况 下, 脚手架的搭设范围要控制在 24 米以内, 并在搭设过程中 将螺栓等连接构件予以稳固。悬挑架则需要依附在建筑本身 结构上, 并利用型钢支撑来提升结构的安全性能。在悬挑架 搭设过程中, 需要注意应将其水平设置在梁上, 相应的针固 位置则需直接固定在主梁及其主梁内的楼板之上, 不可直 接设置在悬挑板和外伸阳台上。再者, 要对支承和建筑结构 之间的关系予以综合考量, 保证设计的合理性, 让其符合国 家规定的基本标准要求。同时在相关参数的计算上,也需做 好反复确认, 确保计算结果的精准性, 提升支承与建筑结构 之间的稳固性, 从而改进高层建筑的施工质量, 减少危险的 发生。

\section{3 混凝土施工技术}

混凝土施工技术是高层建筑施工中最常使用的技术类 型, 同时也是最关键的技术类型。在混凝土施工技术应用过 程中, 其需要关注的重点内容有:

\subsection{1 混凝土配合比}

混凝土配合比的合理性对于增大混凝土强度有着重要 意义。所以在混凝土调配过程中, 要严格按照工程要求确定 原材料的用量以及混合比例, 且通过相关试验来保证混凝土 材料混合后的质量和性能, 保证其强度等级满足高层建筑的 施工要求。同时, 在混凝土调配中, 需要对材料的运输时间和 条件进行了解和掌握。对于高层建筑来说, 一般都是采用泵 送混凝土的方式完成材料供应的。如果混凝土的强度过大, 则不仅会影响整体的施工质量, 同时还会造成输泵管的堵 塞。在混凝土的摚拌工艺时, 要匀速摚拌, 这也是混凝土施工 的重要内容。

\subsection{2混凝土浇筑}

在混凝土浇筑中, 由于水热化反应会导致施工裂缝问题 的出现, 很容易影响高层建筑的施工质量, 增大危险系数。所 
以在浇筑过程中, 要对水化热反应实行合理控制。水泥对于 水化热的影响是最为直接的。在原材料选择上, 如果选用早 强性质的水泥, 相应的水化热反应也会加剧, 使混凝土出现 收缩裂缝, 影响工程质量。所以一般施工中会选用硅酸盐水 泥来实现水化热的合理控制。

在骨料选择上, 应以粒径在 30 毫米左右, 含泥率不超过 $1 \%$ 的粗骨料为主。作为骨料的碎石应该质地坚硬、具有良好 的形状和外观, 防止骨料中含有风化颗粒, 并控制骨料中细 长和片状的颗粒, 其含量不得超过 $10 \%$ 。一般采用中砂作为混 凝土的细骨料, 要求颗粒均匀, 确保砂的整洁, 含泥量应该严 格控制在 $1 \%$ 以内, 细度保持在大约 2.7 的范围之内。另外, 浇 筑施工作业中, 需保证浇筑的连续性, 并对浇筑后的温度实 行合理控制, 以免温度裂缝的产生, 影响整体浇筑效果。

\subsection{3混凝土养护}

混凝土养护是混凝土施工完成后不可忽视的重要环节, 其对于混凝土结构有着很好的保护效果。在养护过程中, 需 要重点注意的内容有以下两点: 其一, 合理控制混凝土温度。 混凝土浇筑完成后, 需要做好相应的保护措施, 以免温差变 化影响混凝土结构内外应力, 造成裂缝的生成。通常情况下, 混凝土浇筑完工后会在其表面附着一层塑料薄膜, 以此来避 免温度和水分的过快散失。其二, 湿度控制。湿度控制主要 是通过定期的表面浇水来实现的, 湿度控制的合理性能够降 低干缩裂缝的产生概率, 增强混凝土的整体性, 减少质量问 题的产生。

\section{4 钢结构施工技术要点}

钢结构施工技术也是高层建筑施工中最常见的施工技 术。在实际使用前, 要对钢结构施工工艺的流程进行了解和 掌握。具体施工工艺流程为:

先做好施工前的准备工作, 减少材料的质量问题; 按照 标准要求进行材料制作和拼装; 做好防腐除锈处理, 并将处 理好的钢结构构件运送到制定施工区域内; 选择合适的吊装 设备实施钢构件的吊装操作, 并设置相应的支撑系统, 保障
结构的安全稳定性; 之后做好结构保护工作, 检查其质量; 开展屋面板、墙面板以及门窗的安装工作; 所有工序完成后, 开始质量验收。

在上述操作环节中, 确保钢结构构建安装的准确性与合 理性是尤为重要的。在构件安装过程中, 需要对图纸中构件 的尺寸、规格予以细致审核, 并确定预埋件混凝土的冻龄。 在保证构件与设计内容相符后, 再开展拼装作业, 且检查其 质量, 以免出现偏差。

\section{5裂缝控制}

裂缝可以说是混凝土建筑中频繁出现的一种问题, 同 时也是建筑企业最为头疼的问题。裂缝产生的原因相对较 多, 如温度裂缝、收缩裂缝等, 故而为避免裂缝的生成, 工作 人员需要结合具体情况, 制定合理的控制措施, 降低裂缝的 影响。首先, 在高层建筑中, 可通过永久伸缩缝、分隔缝等 的设置来减少裂缝问题的出现。其次, 合理配置断面钢筋数 量, 避免应力集中现象的产生; 最后, 合理设置后浇带, 加大 补偿收缩混凝土技术的应用率, 做好混凝土养护工作, 防止 裂缝的产生。

\section{3 结语}

总而言之, 高层建筑已经成为城市建设的重要标志, 其 对于人们生活水平的提高, 以及城市化建设目标的实现有着 重要的现实意义, 所以在实际施工中, 应保证施工技术的选 用和落实的合理性、高效性, 全面改善高层建筑施工质量, 从而满足建筑发展的各项需求。

\section{[参考文献]}

[1]沈斌.高层建筑施工技术要点探析 [ J 科技创新与应 用,2017(6):260.

[2]侯树春.高层建筑施工技术要点探析[J].中国房地产 业,2017(25):108-110。

[3]诸永林.现代高层建筑施工技术要点探析 [ J ] 科技创 新与应用,2014(35):255. 